\title{
Genealogi Studi Hukum Islam di Perguruan Tinggi Keagamaan Islam Indonesia
}

\author{
Wildani Hefni \\ (Fakultas Syariah IAIN Jember Jl. Mataram No. 1 Mangli Jember \\ Email:wildani91@gmail.com)
}

\begin{abstract}
Abstrak
Genealogi studi hukum Islam di lingkungan Perguruan Tinggi Keagamaan Islam berlangsung dinamis dan transformatif. Pembentukan genealogi tersebut tidak bisa dilepaskan dari jaringan keilmuan yang terbentuk sejak berdirinya Perguruan Tinggi Keagamaan Islam. Jaringan keilmuan yang telah terbentuk kemudian memunculkan dua tipologi studi hukum Islam di lingkungan Perguruan Tinggi Keagamaan Islam yaitu kontekstualisasi mazhabi dan rekonstruksi interpretatif. Genealogi ini berjalan dalam jejaring genealogis yang cair tanpa sekat sistem atau batasan formal-struktural dengan menggunakan pendekatan keilmuan sosial. Temuan ini menunjukkan bahwa hukum Islam tumbuh menyatu dengan realitas kehidupan masyarakat yang beragam sehingga diskursus hukum Islam secara dinamis memunculkan nuansa dan perspektif baru yang secara nasab merupakan anotasi dari karya lama dan tumbuh dalam kerangka keragaman, dinamis dan perubahan.
\end{abstract}

Kata Kunci:

Hukum Islam, Genealogi, Perguruan Tinggi Keagamaan, Kontinuitas

\begin{abstract}
Genealogy of Islamic law studies among Islamic universities has become dynamic and transformative. The genealogy has been transformed since the scientific networks existed in state of Islamic university. These networks eventually form two typologies of Islamic law studies which are reconstruction of mazhab and interpretative reconstruction. The genealogical process exists without formal and structural borders while using interdisciplinary approach from social science. It proves that Islamic law has exprienced a dynamic process which is indicated by new perspectives, that rooted from old approaches and
\end{abstract}

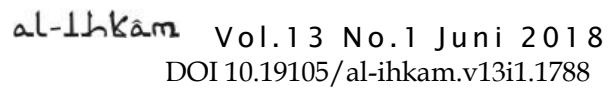


develops in the frame of three principles which are diversity, change and continuity.

Key Words:

\section{Pendahuluan}

Islamic Law, Genealogy, Islamic University, Continuity

Dalam sejarah awal berdirinya, Perguruan Tinggi Keagamaan Islam diwarnai oleh pendekatan kajian normatif doktrinal yang lebih mengedepankan dimensi legal formal Islam (syariah) dan teologi (usul al-din). Dominasi pendekatan normatif-idealistik serta pembatasan pada satu satu aliran pemikiran (school of thought) menyebabkan Perguruan Tinggi Keagamaan Islam berperan sebatas lembaga dakwah.

Memasuki tahun 1970, Perguruan Tinggi Keagamaan Islam mulai terbuka dalam diskurus pemikiran keislaman dengan menciptakan model kajian dan pemahaman yang inklusif, akademis, dan sosiologis yang berbasis pada kajian teks dan analisis sosial. ${ }^{1} \mathrm{Hal}$ ini ditopang eksistensi Perguruan Tinggi Keagamaan Islam seperti Sekolah Tinggi Agama Islam Negeri (STAIN), Institut Agama Islam Negeri (IAIN) dan Universitas Islam Negeri (UIN) yang menstimulasi tumbuhnya kajian hukum Islam dalam pencarian wacana baru bagi pengembangan hukum Islam di Indonesia. ${ }^{2}$

Keberhasilan itu diawali dari upaya reorientasi visi kajian Islam di Perguruan Tinggi Keagamaan Islam dengan heterogenitas pendekatan yang tidak hanya bertumpu pada satu pendekatan atau

\footnotetext{
${ }^{1}$ Marwan Salahuddin, "Model Pengembangan Pendidikan Tinggi Islam di Indonesia," Ulumuna: Jurnal Studi Keislaman, Volume 18, No. 1 (2014): 119121. Marwan menjelaskan tentang filosofi perubahan yang terjadi utamanya dari sisi kelembagaan Perguruan Tinggi Keagamaan Islam yang didasari atas perluasan konteks kajian keislaman yang dikembangkan oleh Perguruan Tinggi Keagamaan Islam.

2 M. Atho Mudzhar, "Kajian Ilmu-Ilmu Syariah di Perguruan Tinggi: Sudahkah Merespon Tuntutan Masyarakat?", Asy-Syir'ah: Jurnal Ilmu Syariah dan Hukum, Vol. 46, No. II, Juli-Desember, (2012): 372-380. M. Atho menjelaskan dengan detail tentang perkembangan kajian studi hukum Islam di Perguruan Tinggi Keagamaan Islam dari waktu ke waktu. Atho juga mengevaluasi apakah perkembangan studi hukum Islam itu telah merespon tuntutan yang dinamis dari masyarakat muslim modern dunia atau tidak.
} 
satu mazhab pemikiran. Kondisi ini mendorong lahirnya pendekatan non-madzhabi dalam kajian hukum Islam di Indonesia.

Pelbagai kajian akademis dosen di Perguruan Tinggi Keagamaan Islam relevan sebagai tolak ukurnya. Geliat kajian akademis di Perguruan Tinggi Keagamaan Islam menunjukkan lahirnya pencarian warna baru bagi pengembangan hukum Islam dengan menggunakan pelbagai pendekatan keilmuan yang kemudian memperlihatkan proses transformasi studi hukum Islam dalam paradigma perubahan dan perkembangan (change and continuity). Dari hal tersebut, geliat pemikiran hukum Islam mengalami pergeseran dan perubahan yang saling merekonstruksi pola dan karakternya yang secara sirkumtansial dipengaruhi oleh setting sosialpolitik, primordialisme organisasi ${ }^{3}$ dan otoritarianisme kuasa. ${ }^{4}$

Penelitian ini termasuk penelitian kepustakaan (library research). Sumber penelitian ini difokuskan pada data-data primer yaitu data dan bahan kajian penelitian dosen-dosen di Perguruan Tinggi Keagamaan Islam. Sedangkan data-data sekunder yang akan menjadi data pendukung adalah literatur yang berkaitan dengan disipilin keilmuan hukum Islam dan karya-karya pendukung dari pemikir lain yang mempunyai sifat relasional, berupa anotasi dari tema-tema pemikiran hukum Islam. Sedangkan pengumpulan data dilakukan dengan menggunakan metode dokumentasi dari referensi dan literatur, serta metodologi yang digunakan, kemudian membuat catatan-catatan terhadap pemikiran dosen yang dituangkan dalam karya-karyanya. Kajian penelitian-penelitian dosen yang mendahului penelitian ini pada dasarnya merupakan penelitian hasil pemikiran keagamaan. Karena itu, analisis data juga menggunakan analisis wacana dan arkeologi pemikiran.

Dalam konteks itu, analisis wacana pemikiran hukum Islam tepat digunakan untuk melihat bagaimana anasir-anasir dalam analisis wacana berproses membentuk sebuah pemikiran, metode bernalar yang secara sistematis mempengaruhi tradisi berpikir. Dari artikel ini, dapat dilihat genesis pemikiran (history of thouhgt),

\footnotetext{
${ }^{3}$ Farid Abdul Khalik, Al-Figh al-Siyasy al-Islamy: Mabadi' Dusturiyah al-Syura al-'Adl al-Musawa (Beirut: Dar al-Fikr, 1991), 162.

${ }^{4}$ Frederick M Denny, "Component of Religion: The Case of Islam" Oxford Journals: OAH Magazine of History, Vol. 6, No. 3 (1992): 23-24.
} 
kerangka keragaman (diversity), perubahan (change) dan perkembangan (continuity) ${ }^{5}$ serta varian pemikiran studi hukum Islam di Perguruan Tinggi Keagamaan Islam.

\section{Bangunan Genealogi Studi Hukum Islam di Indonesia}

Bangunan genealogi dalam hukum Islam terlihat dari genesis pemikiran para sarjana yang dalam setiap generasi melahirkan formulasi baru. Menurut Foucault, logika yang dianggap benar dalam setiap fase sejarah tertentu tidak sama dan tidak diteruskan ke fase sejarah yang selanjutnya. ${ }^{6}$ Dalam konteks hukum Islam, pencarian episteme yang melekat pada sejarah yang bersifat discontinue (keterputusan) menjadi titik awal dari basis genealogi. ${ }^{7}$ Episteme merupakan formasi diskursus yang menjadi kebenaran pada sebuah fase sejarah tertentu yang bersifat keterputusan. Pelacakan genealogi digunakan untuk melacak episteme dalam bahasan yang menyimpang untuk kemudian melihat bahwa masih ada ruang kosong yang dilupakan. $^{8}$

Dalam konteks Indonesia, studi hukum Islam di kalangan intelektual Perguruan Tinggi Keagamaan Islam, dimulai sejak dekade

5 Secara metodologi perubahan dapat dilihat melalui analisa terhadap konteks dan historisitas dimana isu revolusioner ditujukan, kapan dan dimana itu terjadi dengan masalah-masalah yang ditemui. Lihat Anne Marie Moulin, "How To Write The History of Modern Surgery in The Arab and Muslim World?: Methodological Problems and Epistemological Issues:, Majallehye Tarikh-e 'Elm 5, 1385, (2011), 11.

${ }^{6}$ Larry Shiner, "Reading Foucault: Anti Method and The Genealogy of Knowledge", History and Theory, Vol. 21, No. 3 (Oktober 1982): 382.

7 Genealogi merupakan salah satu pendekatan dari sekian banyak pendekatan penelitian kualitatif. Pendekatan ini tidak bisa dilepaskan dari teoritisasi posmodernisme Michel Foucault. Cara kerjanya bertumpu untuk upaya menemukan awal dari sebuah pengetahuan dan bagaimana semua itu terbentuk dalam menjawab semua kebutuhan, bagaimana dimodifikasi dan diganti, membatasi secara efektif yang digunakan, serta seluas apa semua itu diterapkan. Evangelia Sembou, "Foucault's Genealogy", presented at The 10th Annual Meeting of The International Social Theory Consortium, University College Cork, Ireland, 16 - 17 Juni 2011.

${ }^{8}$ Michel Foucault, Nietzsche, Genealogy, History (Ithaca: Cornell University Press, 1977), 139. 
1960-an dengan munculnya ide Fiqih Indonesia melalui tokohnya Hasbi Ash-Shiddiqie. ${ }^{9}$ Pada perkembangannya, gagasan ini dilanjutkan oleh Hazairin dengan tema sentral Fiqih Madzhab Nasional $^{10}$. Awal tahun 1970, Ibrahim Hossen memperkenalkan konstekstualisasi hukum Islam dengan metode ijtihad kontekstual. Performa keilmuan Ibrahim meneguhkan watak ilmu Fikih yang sejatinya dinamis, fleksibel, dan menawarkan banyak pilihan dalam mewujudkan tujuan dasarnya (maqasid al-syariah). ${ }^{11}$

Pada pertengahan tahun 1975, Abdurrahman Wahid mengintrodusir sebuah pemikiran hukum Islam sebagai penunjang pembangunan, yang secara umum mengarahkan pembicaraannya pada peran dan fungsi hukum Islam untuk menunjang perkembangan tata hukum positif di Indonesia. ${ }^{12}$ Pada pertengahan tahun 1980-an, Munawir Syadzali melontarkan gagasan reaktualisasi ajaran Islam dengan mengambil isu-isu pembicaraan mengenai hukum waris, perbudakan, dan bunga bank serta menafsirkannya dengan sangat terbuka. ${ }^{13}$ Dalam pemikiran hukum Islam, juga ada Ahmad Azhar Basyir yang memperkenalkan corak hukum lokal dalam kontestasi hukum Islam di Indonesia. ${ }^{14}$ Pada awal tahun 1990,

\footnotetext{
${ }^{9}$ M Andi Sarjan, "'Hasbi Ash-Shiddiqie wa Tajdid al-Fiqh fi Indunisiya", Studia Islamika, Indonesian Journal for Islamic Studies, Volume 3, No. 3 (1996), 115.

${ }^{10}$ Hazairin, Tujuh Serangkai tentang Hukum (Jakarta: Tintamas, 1874), 12.

11 Ibrahim Hossen, "Kerangka Landasan Pemikiran Islam" dalam Mimbar Ulama, No. 91, (1985). Lihat pula, Ibrahim Hossen, "Fiqih Siyasah dalam Tradisi Pemikiran Islam Klasik", Jurnal Ulumul Qur'an, No. II, (1996). Lihat pula, Profil Prof. KH. Ibrahim Hossen dan Pembaruan Hukum Islam di Indonesia (Jakarta: Tiga Sembilan, 1990).

12 Abdurrahman Wahid, "Hukum Islam sebagai Penunjang Pembangunan", dalam Jurnal Prisma, No. 14, Agustus, (1975).

${ }^{13}$ Munawir Sjadzali, Ijtihad Kemanusiaan (Jakarta: Paramadina, 1997). Lihat pula Muhammad Wahyuni Nafis, Kontekstualisasi Ajaran Islam: 70 Tahun Munawir Syadzali (Jakarta: Paramadina, 1995).

14 Ahmad Azhar Basyir, "Corak Lokal dalam Hukum Positif Islam di Indonesia: Sebuah Tinjauan Filosofis", dalam Mimbar Hukum, No. 13, (1994). Lihat pula, Ahmad Azhar Basyir, Hukum Waris Islam, (Yogyakarta: UII Press, 1982).
} 
muncul pemikiran Ali Yafie $^{15}$ dan Sahal Mahfudh ${ }^{16}$ yang menawarkan pemikiran Fiqh Sosial. Wacana ini menjadi upaya membumikan nilai-nilai fiqh secara holistik dengan fokus pada implementasi ajaran-ajaran fiqh yang berkaitan dengan dimensi kehidupan sosial, relasi individu dengan individu, masyarakat dengan negara dan sebaliknya. Setelah itu, Masdar Farid Mas'udi menggulirkan pemikiran yang dikenal Agama Keadilan sebagai tema sentralnya. ${ }^{17}$

Pada dasarnya, munculnya pelbagai pemikiran tersebut tidak terlepas dari arkeologi pemikiran yang kemudian membentuk teksteks tertulis dan menitikberatkan pada proses terbentuknya ide-ide, pengetahuan dan pemikiran ${ }^{18}$, dalam hal ini pemikiran hukum Islam. Munculnya ide-ide tersebut berjalan sistematis dengan metode nalar yang memengaruhi tradisi berpikir dalam pelbagai pemikiran hukum Islam. $^{19}$

15 Ali Yafie, Menggagas Fiqih Sosial (Bandung: Mizan, 1994). Lihat pula, Ali Yafie "Pemikiran Hukum Islam" dalam Islam Indonesia Menatap Masa Depan, Muntaha Azhari (Ed), (Jakarta: P3M, 1989). Lihat pula Jamal D. Rahman, Wacana Baru Fiqh Sosial: 70 Tahun KH. Ali Yafie (Bandung: Mizan, 1997).

${ }^{16}$ Sahal Mahfudh, Nuansa Figh Sosial, (Yogyakarta: LKiS, 1994). Lihat pula, Sahal Mahfudh, "Ijtihad Sebagai Sebuah Kebutuhan", Majalah Pesantren, No. 2, Vol. II (1985). Lihat pula Sumanto Al-Qurtuby, KH. M.A. Sahal Mahfudh: Era Baru Fih Indonesia (Yogyakarta: Cermin, 1999).

17 Masdar mengambil isu pembahasan yang sensitif dari dimensi ajaran Islam yaitu zakat. Dengan menggunakan pendekatan hisoris-kritis dan kemaslahatan, ia berpendapat bahwa zakat identik dengan pajak. Lihat Masdar F Mas'udi, Agama Keadilan: Risalah Zakat (Pajak) dalam Islam (Jakarta: P3M, 1991).

18 Michel Foucault, The Archeology of Knowledge (London: Tavistock, 1972), 128.

${ }^{19}$ Tentang pola pergeseran kajian studi hukum Islam ini dapat dilihat pada tulisan Noorhaidi Hasan, "Meretas Involusi Kajian Hukum Islam di Indonesia: Pengalaman Fakultas Syariah dan Hukum UIN Sunan Kalijaga Yogyakarta", Asy-Syir'ah: Jurnal Ilmu Syariah dan Hukum, Vol. 46, No. II, JuliDesember, (2012): 388-398. Lihat pula Amin Abdullah, "Bangunan Baru Epistemologi Keilmuan Studi Ilmu Hukum Islam dalam Merespon Globalisasi" dalam Jurnal Asy-Syir'ah: Jurnal Ilmu Syariah dan Hukum, Vol. 46 No II, Juli-Desember (2012): 320-325.. 


\section{Perguruan Tinggi Keagamaan Islam dalam Konteks Perdebatan Hukum Islam}

Secara umum, karakteristik pemikiran sebagaimana disebut di atas telah mengalami kemajuan yang cukup berarti, tidak terkecuali muncul di kalangan Perguruan Tinggi Keagamaan Islam seperti STAIN/IAIN/UIN. Beberapa sarjana di lingkungan Perguruan Tinggi Keagamaan Islam juga turut tampil menjadi pemain kunci dalam peta dan perkembangan hukum Islam di Indonesia. Beberapa intelektual Perguruan Tinggi Keagamaan Islam juga turut mengembangkan model kajian hukum Islam nasionalis-empiris, seperti A. Qodri Azizy (eklektisisme hukum Islam dan hukum nasional), M. Atho Mudzhar (sosiologi hukum Islam), Akh. Minhaji (sejarah sosial pemikiran hukum Islam), dan Nur Fadhil Lubis (hukum Islam kreatif-integratif), serta beberapa intelektual lainnya.

Nur Fadhil Lubis dalam tulisannya mengungkapkan bahwa studi hukum Islam saat ini telah mengalami keberanjakan dari model formal-positivisme menuju pluralisme, dari deductive menuju inductive reasoning, dari disciplinary approach menuju trans-disciplinary approach, dari aspectual menuju holistic coverage, dan dari sectarian menuju cosmopolitanis. ${ }^{20}$ Hukum Islam telah teruji dalam kenyataan sejarah yang berfungsi sebagai sistem hukum yang dinamis dan terarah, yang kreatif namun integratif.

Dalam diskursus eklektisisme hukum Islam, Qodri Azizy ${ }^{21}$ mencoba memadukan antara ilmu hukum Islam dan ilmu hukum

\footnotetext{
${ }^{20}$ Nur A. Fadhil Lubis, "Islamic Legal Studies in Indonesia: Some Notes on Contemporary Challenges" dalam Proceeding AICIS XII (Jakarta: Direktorat Pendidikan Tinggi Islam, 2012), 5-8. Lihat juga Nur A. Fadhil Lubis, "Mengembangkan Studi Hukum Islam" dalam Komaruddin Hidayat dan Hendro Prasetyo, Problem dan Prospek IAIN: Antologi Pendidikan Tinggi Islam (Jakarta: Kementerian Agama, 2000), 291.

${ }^{21}$ A. Qodri Azizy adalah intelektual-birokrat yang ide dan gagasannya begitu berpengaruh dalam konteks pengembangan studi Islam integratif di lingkungan perguruan tinggi keagamaan Islam Indonesia. Memperoleh gelar MA dan Ph.D dari The University of Chicago, Amerika Serikat. Pernah menjabat sebagai Rektor IAIN Walisongo Semarang dan juga Dirjen Bagais Departeman Agama. Dalam konteks perkembangan kajian hukum Islam, Qadri menjadi salah satu tokoh yang turut berkontribusi dengan ide-de
} 
umum dengan menggunakan istilah eklektisisme. Dengan istilah "eklektik", Qodri menawarkan konsep ilmu hukum Indonesia atau Indonesian Jurisprudence. Pelbagai tantangan dan tuntutan modernitas menurut Qodri menjadi suatu hal yang nyata didepan perkembangan kajian hukum Islam. Maka, model, pendekatan, dan filosofi kajian hukum Islam atau fikih baik di lingkungan STAIN, IAIN atau UIN serta Perguruan Tinggi Keagamaan Islam Swasta (PTKIS) perlu diadakan reorientasi atau bahkan perubahan agar benar-benar bermanfaat dan memenuhi tuntutan modernitas. ${ }^{22}$ A. Qodri Azizy hendak melakukan positivisasi hukum Islam dalam konteks kajian akademik dengan selalu mengikuti eklektisisme maupun proses demokratisasi yang berdasarkan pada mayoritas penduduk.

Salah satu intelektual di dunia Perguruan Tinggi Keagamaan Islam di Indonesia yang juga memiliki ide dan gagasan dalam kajian hukum Islam adalah Atho Mudzhar. ${ }^{23}$ Dalam melakukan kajian dan pendekatan terhadap hukum Islam, Atho menggunakan pendekatan sosiologi hukum Islam. Misalnya, pada tanggal 15 September 1999, dalam pidato pengukuhan Guru Besar, Atho menulis Studi Hukum

pembaharuannya. Qadri lahir di Kendal, 24 Oktober 1955. Karya-karyanya antara lain Islam dan Permasalahan Sosial: Mencari Jalan Keluar (Yogyakarta: LKiS, 2002), Pengembangan Ilmu-Ilmu Keislaman (Direktorat Perguruan Tinggi Agama Islam: 2004), Hukum Nasional: Eklektisisme Hukum Islam dan Hukum Umum (Jakarta: Teraju, 2004), Menggagas Hukum Progresif di Indonesia (Yogyakarta: Pustaka Pelajar, 2006). Lihat Abdul Rouf, Jejak IntelektualBirokrat: Meneladani Kearifan Prof. Dr. A. Qodri Azizy (Jakarta: Linus, 2013), 136.

${ }^{22}$ A. Qodri Azizy, Eklektisisme Hukum Nasional: Kompetisi Antara Hukum Islam dan Hukum Umum (Yogyakarta: Gama Media, 2002), 252.

${ }^{23}$ M. Atho Mudzhar adalah guru besar hukum Islam di Universitas Islam Negeri Syarif Hidayatullah. Atho lahir di Serang, 20 Oktober 1948. Pernah menjabat sebagai Rektor IAIN Sunan Kalijaga Yogyakarta (1996-2001). Memperoleh gelar Ph.D dalam studi Islam dari University of California Los Angeles (UCLA), USA (1990). Atho dikenal sebagai penggagas studi hukum Islam dengan pendekatan sosiologi. Karya-karya dalam studi hukum Islam menggunakan pendekatan sosiologi antara lain, H.M. Atho Mudzhar, Pendekatan Studi Islam Dalam Teori dan Praktek (Yogyakarta: Pustaka Pelajar, 1998), Atho Mudzhar, "Social History Approach to Islamic Law," Jurnal AlJamiah, No. 61 (1998). 
Islam dengan Pendekatan Sosiologi. Pada bagian akhir naskah pengukuhan Guru Besar tersebut, Atho secara tegas mengatakan bahwa penerapan pendekatan sosiologi dalam studi hukum Islam berguna untuk memahami secara lebih mendalam gejala-gejala sosial di seputar hukum Islam. Pendekatan ini akan membantu untuk memperdalam pemahaman hukum Islam doktrinal, baik pada tatanan hukum asas maupun normatif, dan pada gilirannya membantu memahami dinamika hukum Islam. ${ }^{24}$

Sementara dalam konteks sejarah pemikiran hukum Islam, Akh. Minhaji ${ }^{25}$ melontarkan gagasan bahwa dalam sejarahnya yang panjang, hukum Islam berkelindan lahir dari kekuatan hukum adat sebagai perwakilan aspek lokalitas. Hukum Islam dan tradisi lokal menurut Minhaji selalu akan bergandengan dimana keduanya akan saling berkesinambungan satu sama lain. Hukum Islam tak lain adalah implementasi dari tradisi lokal sehingga hukum Islam pada tataran aplikasinya akan berubah-ubah di setiap daerah karena adanya perbedaan tradisi lokal, waktu, dan tempat. ${ }^{26}$

\section{Arkeologi Pengetahuan dalam Studi Hukum Islam Indonesia}

Dari waktu ke waktu, pencarian model formulasi hukum Islam menjadi jantung pergulatan konstruksi hukum Islam yang senantiasa berubah seiring dengan proses historisasi dan transformasi yang dimunculkan dalam diskursus intelektual ${ }^{27}$ tentang hukum

\footnotetext{
${ }^{24}$ M. Atho Mudzhar, "Studi Hukum Islam dengan Pendekatan Sosiologi" dalam Seri Kumpulan Pidato Guru Besar: Rekonstruksi Metodologi Ilmu-Ilmu Keislaman (Yogyakarta: Suka Press, 2003), 173-209.

${ }^{25}$ Akh. Minhaji adalah guru besar di UIN Sunan Kalijaga Yogyakarta. Pernah menjabat sebagai Rektor UIN Sunan Kalijaga Yogyakarta. Ia memperoleh gelar Ph.D dalam bidang sejarah hukum Islam dari McGill University dengan disertasi Ahmad Hassan and Islamic Legal Reform Indonesia 1887-1958.

${ }^{26}$ Akh. Minhaji, Islamic Law and Local Tradition: A Socio Historical Approach (Yogyakarta: Kurnia Kalam Semesta Press, 2008), 3.

${ }^{27}$ Dalam bahasa Collins, dirkursus intelektual digambarkan dengan sebuah konflik. Konflik intelektual yang dimaksud adalah kontestasi pemikiran yang dibatasi oleh fokus perhatian pada topik-topik tertentu serta usaha untuk mencari sekutu. Konflik merupakan sumber energi dari kehidupan intelektual dan konflik intelektual dibatasi oleh dirinya sendiri. Lihat $\mathrm{R}$.
} 
Islam di kalangan para sarjana. Dirkursus yang mengemuka diantara tradisi-tradisi intelektual yang berbeda tidak mesti mengarah untuk saling menafikan karena sejatinya hal tersebut mengarah untuk saling mendekat. Diskursus formulasi hukum Islam antara generasi pertama dan generasi selanjutnya mendorong perumusan hukum Islam yang dinamis, aplikatif dan emansipatoris. Proses pencarian model ini kemudian membentuk elemen-elemen sosial yang saling bersinggungan membangun kerangka bersama antar beragam kelompok dalam sebuah genealogi untuk melakukan afiliasi ganda (multiple affiliations) dalam hukum Islam ${ }^{28}$.

Setiap generasi hadir dengan perbedaan dalam kerangka pikir dan minat pengetahuan, perbedaan akses, perbedaan dalam wacana serta perbedaan dalam ideologi dan identitas. Dengan kata lain, pencarian model hukum Islam disepanjang gerak kontinuitas yang bersifat diakronik, terjadi perubahan-perubahan yang bersifat sinkronik. Terdapat jaringan diakronik yang bersifat lintas generasi yang memungkinkan terciptanya kontinuitas perkembangan hukum Islam yang tidak bisa dilepaskan dari pengaruh generasi sebelumnya. Adanya keterhubungan pemikiran dalam reproduksi dan reformulasi hukum Islam antar generasi menunjukkan bahwa sesungguhnya tidak ada originalitas dalam gagasan-gagasan dari generasi tertentu. Relasi dari mata rantai intelektual dalam sejarahnya yang panjang menjadi skema genealogi.

\section{Pembentukan Tradisi Pembaruan Hukum Islam di Perguruan Tinggi Keagamaan Islam}

Pembentukan intelektualisme dalam studi hukum Islam di lingkungan Perguruan Tinggi Keagamaan Islam bukanlah sesuatu yang datang secara tiba-tiba. Dalam proses itu terdapat keterkaitan dan kesinambungan (continuity) dengan perkembangan pemikiran yang ditandai dengan dialektika keilmuan. Di samping ada kontinuitas, juga terjadi perubahan (change) secara dinamis atas tradisi sebelumnya. Dengan kata lain, terdapat kebuntuan yang

Collins, The Sociology of Philosophies: A Global Theory of Intellectual Change (Massachusetts: The Belknap Press of Harvard University Press, 1998), 73.

28 Herbert J. Liebesny, "Stability and Change in Islamic Law," Middle East Journal, Vol. 21, No. 1 (Winter 1967): 16-19. 
kemudian diurai kembali. Kaitannya dengan hal ini, Michel Foucault telah mencoba melakukan kritik sejarah untuk menciptakan jalan baru bagi kebuntuan rasionalitas sejak abad klasik. ${ }^{29}$ Dalam pandangan Foucault, kebuntuan harus dipecahkan dengan menyusun ulang retakan dan pecahan memori serta pengetahuan yang sempat terkubur dalam strategi-strategi pendisiplinan struktur pikir masyarakat.

Maka dalam konteks menemukan retakan dan pecahan ide tentang epistema studi hukum Islam di lingkungan Perguruan Tinggi Keagamaan Islam, perlu dilihat akar dari proses pembentukan intelektualisme pemikiran hukum Islam tersebut. Hal itu dapat dilacak jauh ke belakang sejak proses berdirinya IAIN. Tanggal 24 Agustus 1960, Presiden Republik Indonesia mengeluarkan Peraturan Pemerintah No. 11 yang menggabungkan PTAIN dan ADIA dengan nama baru yaitu Institut Agama Islam Negeri (IAIN) yang berpusat di Yogyakarta. Prof. Mr. R.H.A Soenarjo ditunjuk sebagai rektor dibantu Prof. T.M. Hasbi ash-Shiddiqie sebagai Dekan Fakultas Syariah ${ }^{30}$ yang berkedudukan di Yogyakarta. ${ }^{31}$

Di lingkungan Perguruan Tinggi Keagamaan Islam, Hasbi sebagai dekan pertama Fakultas Syariah IAIN Sunan Kalijaga dikenal sebagai penggagas Fikih Indonesia. Munculnya gagasan Fiqh Indonesia melalui Hasbi ash-Shiddiqie ${ }^{32}$ menjadi penanda lahirnya

\footnotetext{
${ }^{29}$ Michel Foucault, The Archaeology of Knowledge (New York: Pantheon Books, 1972), 243. Dalam konteks ini, Foucault melaju pada sebuah kesimpulan bahwa pembentukan dan pendisiplinan tubuh pengetahuan dapat ditempuh dengan strategi pertarungan wacana, taktik klasifikasi, serta normalisasi.

${ }^{30}$ Dalam peralihan PTAIN menjadi IAIN terdapat tiga jurusan yaitu Syariah, Tarbiyah dan Dakwah. Bersamaan dengan hal itu, Hasbi diangkat menjadi Dekan Fakultas Syariah berdasarkan Keputusan Menteri Agama Nomor 5 Tahun 1960. Lihat Nourozaman Shiddiqie, "Prof. Dr. Tengku Muhammad Hasbi as-Shiddiqiy" dalam Moh Damami, Lima Tokoh Pengembangan IAIN Sunan Kalijaga (Yogyakarta: Pusat Penelitian IAIN Sunan Kalijaga, 1998), 171.

${ }^{31}$ Fuad Jabali dan Jamhari, IAIN dan Modernisasi Islam di Indonesia (Jakarta: Logos, 2002), 13.

32 Hasbi ash-Shiddiqie adalah tokoh penggagas Fiqih dengan kepribadian Indonesia. Pada tahun 1960 menjabat sebagai Dekan Fakultas Syariah IAIN Sunan Kalijaga Yogyakarta. Pelbagai studi dan penelitian mencoba memotret pemikiran, aktivitas, karya ilmiah, dan kontribusi Hasbi ash-Shiddiqie dalam
} 
perkembangan hukum Islam yang lebih cocok dengan kebutuhan masyarakat. Karena itu, ia menawarkan hukum Islam yang sesuai dengan sosiokultur dan religi masyarakat Indonesia. Gagasan Hasbi menjadi penggerak lahirnya pemikiran dan ide-ide tentang hukum Islam Indonesia yang membumi.

Selain Hasbi, seorang tokoh pembaharu hukum Islam yaitu Hazairin $^{33}$ membentuk fiqh Madzhab Nasional Indonesia yang kemudian menjadi diskursus besar di lingkungan perguruan tinggi keagamaan Islam. Di lingkungan PTIQ dan IAIN (sekarang UIN) Syarif Hidayatullah Jakarta, pada awal tahun 1970 muncul tokoh bernama Ibrahim Hossen, Munawir Syadzali, Ahmad Azhar Basyir dan beberapa tokoh lainnya.

Sedangkan beberapa sarjana di lingkungan Perguruan Tinggi Keagamaan Islam juga turut tampil menjadi pemain kunci dalam peta dan perkembangan hukum Islam. ${ }^{34}$ Beberapa intelektual Perguruan Tinggi Keagamaan Islam juga turut mengembangkan model kajian hukum Islam nasionalis-empiris, seperti A. Qodri Azizy (eklektisisme hukum Islam dan hukum nasional), M. Atho Mudzhar (sosiologi hukum Islam), Akh. Minhaji (sejarah sosial pemikiran hukum Islam), dan Nur Fadhil Lubis (hukum Islam kreatif-integratif).

Tradisi kesarjanaan yang telah dilakukan oleh para pendahulu itu kemudian menjadi referensi yang terus dilakukan oleh para dosen dalam melakukan pelbagai kajian dan penelitian tentang hukum Islam di Indonesia. Para dosen berkontribusi positif dengan menyelenggarakan program studi hukum Islam yang kondusif dan relevan. Studi hukum Islam di Perguruan Tinggi Keagamaan Islam (STAIN/IAIN/UIN) perlahan berhasil mengukir nama baiknya

bidang keilmuan Islam. Lihat, Nourouzzaman Siddiqi, Figh Indonesia: Penggagas dan Gagasannya (Yogyakarta: Pustaka Pelajar, 1997). Bandingkan dengan M. Andi Sarjan, "'Hasbi Ash-Shiddiqie wa Tajdid al-Fiqh fi Indunisiya," Studia Islamika, Indonesian Journal for Islamic Studies, Volume 3, No. 3 (1996): 115.

${ }^{33}$ Hazairin adalah tokoh pembaharu hukum Islam Indonesia yang dikenal dengan ide dan gagasannya tentang hukum adat.

${ }^{34}$ Waryani Fajar Riyanto, Mazhab Sunan Kalijaga: Epistemologi Studi Hukum Islam Integratif (Yogyakarta: Kurnia Kalam Semesta dan Fakultas Syariah UIN Sunan Kalijaga Yogyakarta: 2014) , 602. 
dalam khazanah pemikiran dan pengembangan sistem hukum nasional di Indonesia. Pelbagai pendekatan dan metodologi dalam tradisi pembentukan intelektualisme dalam panggung keilmuan studi hukum Islam di Perguruan Tinggi Keagamaan Islam turut menjadi modal besar. Dengan kata lain, ada modal sosial dan intelektual yang dimiliki oleh para dosen dalam proses mengkaji dan meneliti bidang keilmuan hukum Islam. setidaknya, ada dua kekuatan besar yang dimiliki oleh para dosen di lingkungan Perguruan Tinggi Keagamaan Islam dalam mengkaji studi hukum Islam. Dua kekuatan inilah yang kemudian mengantarkan mereka dalam mata raitai intelektual yang dinamis dan transformatif tanpa dipengaruhi sekat apapun. Kajian studi hukum Islam di Perguruan Tinggi Keagamaan berkembang pesat dengan dua modal dan sarana sebagai berikut:

\section{Modal Sosial-Intelektual Dosen Perguruan Tinggi Keagamaan Islam}

Modal sosial merupakan landasan sosio kultural yang mencakup nilai-nilai, norma-norma, relasi-relasi, pandangan hidup, ikatan solidaritas dan sebagainya. Penyebutan modal sosial biasanya menunjuk pada institusi-institusi, hubungan-hubungan dan normanorma yang mempunyai pengaruh dalam membentuk dan menentukan kualitas dan kuantitas interaksi sosial dalam masyarakat. Dalam pengertian yang lebih luas, modal sosial mencakup pelbagai aspek positif dan negatif dari pelbagai kelompok yang ada dalam masyarakat, perilaku, serta sumber yang ada didalamnya.

Modal sosial bisa menampakkan dalam pelbagai saluran. Pertama, saluran-saluran informasi yang ada dalam masyarakat sebagai sarana untuk melakukan penyebaran gagasan. Kedua, normanorma resiprositas yang keberlangsungannya tergantung pada jaringan sosial yang mempertemukan pelbagai individu. Ketiga, tindakan kolektif yang dilakukan oleh jaringan sosial yang dimiliki. Keempat, identitas dan solidaritas yang lebih luas muncul sebagai hasil dari jaringan sosial yang telah dibangun. ${ }^{35}$ Menurut Bourdieu, definisi modal sosial adalah jumlah sumber-sumber daya, aktual atau virtual yang berkembang pada seorang individu atau sekelompok individu

35 James S. Coleman, "Social Theory, Social Research: A Theory of Action", American Journal of Sociology , No. 91, (1986), 1309-1335 
karena kemampuan untuk memiliki suatu jaringan yang dapat bertahan lama dalam hubungan-hubungan yang lebih kurang telah diinstitusikan berdasarkan pengetahuan dan pengenalan timbal balik. $^{36}$

Sedangkan modal intelektual berada pada tempat strategis dalam konteks kinerja. Drucker misalnya meramalkan datangnya dan sekaligus mendeskripsikan pergeseran ke arah era masyarakat pengetahuan (knowledge society). Dalam sebuah komunitas akademik, pengetahuan juga kapabilitas untuk belajar (learning capability) dalam membangun basis-basis intelektual merupakan penggerak perubahan yang cepat dan karenanya manusia sebagai pekerja pengetahuan (knowledge worker) menjadi aktor utamanya. ${ }^{37}$

Sesuai dengan teori modal sosial-intelektual yang ada, maka para akademisi di lingkungan perguruan tinggi keagamaan diposisikan sebagai pelaku historis yang memengaruhi disatu sisi, namun juga dipengaruhi disisi lain sehingga relasi jejaring intelektual tumbuh dari tradisi akademik perguruan tinggi. Selain itu, modal intelektual digunakan dalam mewacanakan pelbagai diskursus untuk menciptakan, melakukan transfer, dan mengimplementasikan ilmu pengetahuan.

Di kalangan Perguruan Tinggi Keagamaan Islam, sebagaimana diungkapkan Musahadi, pada awal tahun 1970-an, membicarakan penelitian tentang agama masih dianggap tabu. ${ }^{38}$ Secara historis, pengembangan ilmu-ilmu keagamaan masih berputar pada level dogmatis-normatif yang ditandai dengan Fakultas Syariah, Ushuludin, Adab dan Tarbiyah dalam bingkai pemahaman teologis yang diperkenalkan oleh para alumni Timur Tengah yang muncul pada periode 1950-an hingga tahun 1970-an. Memasuki pertengahan tahun 1970, tradisi tersebut mulai bergeser dengan ditandai para sarjana Perguruan Tinggi Keagamaan Islam yang belajar ke Barat.

\footnotetext{
${ }^{36}$ Pierre Bourdieu, An Invitation to Reflexive Sociology (Chicago: University of Chicago Press, 1992), 28.

${ }^{37}$ Peter F. Drucker, Manajemen di Tengah Perubahan Besar (Jakarta: Elex Media Komputindo, 2000), 91.

${ }^{38}$ Musahadi, "Islam sebagai Sasaran Studi: Indentifikasi Awal terhadap Problem, Pola, dan Pendekatan Studi Islam di Indonesia", dalam Proceeding ACIS V, (Jakarta: Direktorat Pendidikan Tinggi Islam, 2005), 235.
} 
Pada era tahun 1950 hingga tahun 1970, secara umum corak atau kecendrungan kajian Islam di lingkungan perguruan tinggi keagamaan bersifat normatif. Hal ini berbeda dengan dekade tahun 1970-an yang lebih mengarah kepada kajian Islam yang terkait dengan konteksnya, bersifat sosio-kultural yang menyejarah. Barometer gerakan pembaruan itu menemukan momentum awal dimana mulai muncul tokoh-tokoh intelektual Islam seperti H.M Rasjidi, Mukti Ali, Harun Nasution, Nurcholis Madjid mereorientasi arah kajian Islam di IAIN. ${ }^{39}$ Hal ini didukung dengan arus kebijakan pemerintah mengirimkan para sarjana untuk belajar ke luar negeri dan menjadi penanda awal terbukanya iklim akademik di lingkungan Perguruan Tinggi Keagamaan Islam.

Ledakan alumni doktor luar negeri ini menjadi penanda semakin berkembangnya wacana intelektual di lingkungan Perguruan Tinggi Keagamaan Islam dengan diwarnai semangat tradisi akademik dan intelektual yang lebih terbuka, kritis, dan progresif.

\section{Tradisi Penelitian Sebagai Basis Transformasi Keilmuan}

Program bantuan dana penelitian Direktorat Pendidikan Tinggi Keagamaan Islam Direktorat Jenderal Pendidikan Islam Kementerian Agama Republik Indonesia merupakan salah satu program penunjang untuk mendukung para dosen melakukan tradisi akademik dan juga sebagai implementasi dari tri dharma perguruan tinggi. Program bantuan penelitian juga merupakan komitmen Direktorat Pendidikan Tinggi Keagamaan Islam untuk memberikan akses yang luas bagi dosen dalam rangka peningkatan kapasitas (capacity building), khususnya pada ranah akademik.

Secara umum, program bantuan peningkatan mutu penelitian memfasilitasi upaya pengembangan bidang ilmu yang dikembangkan di Perguruan Tinggi Keagamaan Islam yaitu Islamic studies maupun kajian disiplin ilmu umum. Di samping konsen terhadap pengembangan bidang ilmu, program bantuan peningkatan mutu penelitian memberikan ruang yang cukup lapang untuk aksi

${ }^{39}$ Syamsun Ni'am, “Reformulasi Paradigma Kajian Keislaman di Perguruan Tinggi Agama Islam", dalam Proceeding ACIS IX, (Jakarta: Direktorat Pendidikan Tinggi Islam, 2009), 125. 
partisipatif, dimana penelitian tidak hanya mengetahui, menjelaskan atau menafsirkan namun juga mentransformasi kondisi sosial khususnya penguatan kualitas hidup komunitas Muslim.

Target yang hendak dicapai dari program bantuan penelitian di lingkungan Perguruan Tinggi Keagamaan Islam adalah tampilan nalar akademik dan dinamika intelektual yang maksimal. ${ }^{40}$ Karena itu, beberapa target jangka pendek di bidang penelitian cukup tinggi.

Dalam konteks demikian, para dosen di lingkungan Perguruan Tinggi Keagamaan Islam dapat berpartisipasi dalam rangka mewujudkan tradisi akademik sebagai basis transformasi keilmuan yang dinamis dengan melakukan pelbagai kajian, termasuk salah satunya dalam bidang hukum Islam. Program bantuan penelitian merupakan program untuk menunjang tradisi akademik di lingkungan Perguruan Tinggi Keagamaan Islam dalam menghasilkan pelbagai hasil kajian serius dari kalangan intelektual akademik Indonesia dan menjadi bukti narasi intelektualisme Indonesia berkontribusi bagi peradaban dunia.

Dalam konteks ini, senafas tumbuhnya kesadaran tentang pentingnya mengaktualisasi kajian Islam dengan semangat perubahan zaman, kajian penelitian yang diterbitkan dalam karya ilmiah di kalangan dosen Perguruan Tinggi Keagamaan Islam berkembang pesat dengan memanfaatkan dan mengintegrasikan ilmu-ilmu sosial ke dalam paradigma, metode dan konstruk analisisinya. Kelebihan yang dimiliki dari karya-karya intelektual Indonesia adalah kemampuannya mempertemukan hubungan dua arah yang bercorak diadik yaitu perjumpaan Islam dengan budaya lokal yang kemudian diuraikan dalam diskursus lokalitas dan globalitas. Hasil penelitian itu adalah hasil interaksi dengan sarjana-

${ }^{40}$ Program bantuan peningkatan mutu penelitian merupakan dana bantuan penelitian yang disediakan untuk meningkatkan kualitas kajian disiplin ilmu menurut bidang keilmuan, yang diperuntukkan bagi para dosen dan fungsional peneliti di lingkungan Perguruan Tinggi Keagamaan Islam dalam setiap tahun anggaran berjalan. Program ini diharapkan menghasilkan hasil riset yang dapat dipublikasikan dalam jurnal ilmiah nasional dan internasional sesuai dengan "core competency" rumpun ilmu masing-masing. Lihat tim Direktorat Pendidikan Tinggi Islam, Buku Petunjuk Teknis Penelitian, Publikasi Ilmiah dan Pengabdian Kepada Masyarakat (Jakarta: Direktorat Pendidikan Tinggi Islam, 2016), 14-17. 
sarjana masa sebelumnya yang diuraikan dengan simpul analisis sosial. Analisis sosial inilah yang menginspirasi karya, statemen, sensivitas antropologis, dan tipologi keilmuan yang dibangun. ${ }^{41}$

\section{Fase Transformasi Studi Hukum Islam di Perguruan Tinggi Keagamaan Islam}

Bergesernya pemikiran hukum Islam dari yang berparadigma "kebenaran ortodoksi" menjadi paradigma pemaknaan sosial, dari yang berwatak hitam-putih menjadi bernuansa sekaligus kaya perspektif menggambarkan adanya kemajuan keluwesan yang dialami oleh hukum Islam. Perubahan (change) semacam itu merupakan konsekuensi logis dari ciri keluwesan tersebut. Hal ini terbaca dari adanya upaya terus-menerus dosen di lingkungan Perguruan Tinggi Keagamaan Islam untuk melakukan penggalian, penemuan, penyesuaian, dan penyaringan dari perubahan yang terjadi. Proses transformasi tersebut dapat dijelaskan dalam fase perjalanan dari proses pencarian format pemikiran hukum Islam di lingkungan Perguruan Tinggi Keagamaan Islam untuk mengetahui sejarah dan genealogi pemikirannya.

Secara genealogis, pencarian format tersebut dapat dipetakan dalam tiga fase yang saling berhubungan. Tiga fase ini menggambarkan kemunculan para intelektual akademik di lingkungan Perguruan Tinggi Keagamaan Islam memunculkan sekaligus menemukan model dan paradigma pendekatan dalam hukum Islam.

\section{Pencarian Awal Kiblat Studi Hukum Islam}

Dalam sejarah awal berdirinya, Perguruan Tinggi Keagamaan Islam pernah diwarnai oleh pendekatan kajian normatif doktrinal yang lebih mengedepankan dimensi legal formal Islam dan teologi. Hasil dari pendekatan ini adalah munculnya kecenderungan kajian Islam yang sangat skriptural, mengacu kepada praktik-praktik ibadah dan akidah dalam Islam. Hal ini disebabkan oleh dominasi pendekatan normatif-idealistik yang dikembangkan di sejumlah

${ }^{41}$ Koichiro Misawa, "A Critical Analysis of The Educational Impact of Analytic Social Epistemology," Journal of Studies in Education 2, 3 (2012), School of Education, Japan, Tokyo University of Social Welfare. 
perguruan tinggi Islam Timur Tengah, utamanya al-Azhar Kairo yang pada mulanya menjadi imam bagi Perguruan Tinggi Keagamaan Islam dari segi metodologi mendekati Islam. ${ }^{42}$ Bahkan, madzhab pemikiran Islam yang lain tidak dipelajari karena dianggap akan menyesatkan bangunan keimanan mereka. ${ }^{43}$

Paradigma demikian berlangsung dari sejak berdirinya perguruan tinggi keagaaman sampai era 1970-an. Fase ini berjalan cukup lama dalam pencarian kiblat studi hukum Islam di lingkungan Perguruan Tinggi Keagamaan Islam. Fase ini mulai mengalami perubahan akibat perkembangan ilmu pengetahuan dan teknologi di era globalisasi yang diikuti munculnya persoalan-persoalan baru dimana Perguruan Tinggi Keagamaan Islam dituntut kontribusinya untuk memecahkan persoalan-persoalan secara cerdas dan kreatif. Melalui model pendekatan integratif yang diinisiasi oleh intelektual akademik Perguruan Tinggi Keagamaan Islam, bidang-bidang kajian yang dikembangkan menjadi lebih luas.

\section{Pembentukan Kiblat Studi Hukum Islam}

Pada era 1950 hinga 1970-an, secara umum corak atau kecenderungan kajian Islam, termasuk hukum Islam di Perguruan Tinggi Keagamaan Islam bersifat normatif. Namun, hal ini berbeda dengan dekade tahun 1980-an yang lebih mengarah pada kajian Islam dengan pendekatan sosiologis yang erat kaitannya dengan konteks, bersifat sosio-kultural yang menyejarah. ${ }^{44}$ Kajian hukum Islam tidak lagi berputar-putar pada mata rantai teosentrik dan bersifat politisideologis, tetapi masuk dalam ruang kultural, universal, antroposentrik, dan filosofis-sosiologis. ${ }^{45}$

\footnotetext{
${ }^{42} \mathrm{M}$ Atho Mudzhar, Pendekatan Studi Islam Dalam Teori dan Praktik (Yogyakarta: Pustaka Pelajar, 2007), 28.

${ }^{43}$ Marwan Salahuddin, "Model Pengembangan Pendidikan Tinggi Islam di Indonesia," Ulumuna: Jurnal Studi Keislaman, Volume18, No. 1 (2014): 119-121.

${ }^{44}$ Nur Fadhil Lubis, Hukum Islam dalam Kerangka Teoritis Fiqh dan Tata Hukum Indonesia (Medan: Pustaka Widyasarana, 1995), 127. Lihat pula, Nur Fadhil Lubis, "Islamic Legal Literature and Substantive Law in Indonesia" Studia Islamika, Indonesian Journal for Islamic Studies, Volume 4, No. 4, (1997), 35-45.

${ }^{45}$ Arskal Salim, Contemporary Islamic Law in Indonesia: Sharia and Legal Pluralism (Edinburgh: Edinburgh University Press, 2015), 38. Lihat pula M.
} 
Kecenderungan kajian hukum Islam yang demikian normatif teologis sebagaimana tergambar diatas tidak berlangsung lama sebab kecenderungan baru muncul sebagai respons Perguruan Tinggi Keagamaan Islam terhadap fenomena pembangunan dan perubahan zaman. Disamping itu, perubahan pendekatan semakin diperlancar dengan dikirimkannya para intelektual muda Muslim ke Barat untuk meneruskan jenjang studinya. ${ }^{46}$

\section{Pelestarian Kiblat Studi Hukum Islam}

Seturut tuntutan yang semakin meningkat bagi civitas akademika perguruan tinggi keagamaan untuk mengembangkan kompetensi keilmuan masing-masing, pemahaman yang lebih utuh terhadap ilmu sosial berkembang signifikan sebagai kerangka pendekatan yang diyakini berguna untuk memperkaya kajian hukum Islam. Filsafat, sosiologi, antropologi, psikologi dan bidang keilmuan lainnya, bukan barang asing bagi para dosen. Para intelektual Perguruan Tinggi Keagamaan Islam menggunakan pendekatan kontekstual dengan mendialogkan teks dengan konteks sekaligus mendapatkan makna-makna dan interpretasi baru dalam persentuhannya dengan praktik-praktik sosial yang lain.

Tiga fase sebagaimana tergambar di atas menunjukkan bahwa kajian hukum Islam di lingkungan Perguruan Tinggi Keagamaan Islam tidak bisa lepas dari kehadiran dan pengaruh orang lain yang penting (significant others). Persepsi intelelektual Perguruan Tinggi Keagamaan Islam yang berbeda-beda atas penafsiran hukum Islam, telah melahirkan strategi-strategi kuasa dan formulasi-formulasi identitas yang berbeda-beda. Sepanjang abad ke dua puluh, intelektual Perguruan Tinggi Keagamaan Islam telah berhadapan dengan tantang serius dari begitu cepatnya arus modernisasi yang telah mengubah beberap aspek fundamental dari kondisi sosial masyarakat. Di sisi lain, menguatnya pengaruh pendidikan (baik dari Barat ataupun Timur Tengah) dalam wacana hukum Islam juga

Hasyim Kamali, "Fiqh Adaptation to Social Reality", dalam The Muslim Word, Vol. XXXXVI, No. 1, 1996.

${ }^{46}$ Margaret Gillet, "The IAIN in Indonesian Higher Education" dalam Muslim Education Quarterly, Vol. 8, No. 1, (1990), 21-26. 
merupakan sebuah fakta terdorongnya para dosen untuk melakukan kajian hukum Islam secara ilmiah. Dialektika keilmuan terus berlanjut dan menjadi tradisi dari basis transformasi keilmuan. (Tabel genealogi studi hukum Islam di Perguruan Tinggi Keagamaan Islam Indonesia sebagaimana terlampir).

\section{Penutup}

Genealogi studi hukum Islam di Perguruan Tinggi Keagamaan Islam tidak bisa dilepaskan dari jaringan keilmuan yang terbentuk sejak berdirinya Perguruan Tinggi Keagamaan Islam pada tahun 1960. Jaringan keilmuan dibagi dalam tiga fase. Fase pertama (1960-1980) adalah fase pencarian kiblat kajian hukum Islam Indonesia yang dibangun oleh Hasbi as-Shiddiqie, Hazairin, Munawir Syadzali dalam konstruksi pendekatan normatif-teologis. Fase kedua (1980-2000) adalah fase pembentukan kiblat studi hukum Islam Indonesia yang dipelopori oleh alumni Barat dengan pendekatan sosiologis-historis yang dipelopori oleh Akh. Minhaji, A. Qodry Azizy, M. Atho Mudzhar dan intelektual lainnya. Fase ketiga (20102015) adalah fase pelestarian kiblat studi hukum Islam dengan dibekali penguatan tradisi penelitian yang kuat dan dipelopori para intelektual Perguruan Tinggi Keagamaan Islam dengan memadukan keilmuan Barat dan Timur Tengah menggunakan pendekatan integratif-konstruktif.

Perubahan dalam struktur pemikiran ke arah modernisasi pengetahuan tersebut menjadi basis transformasi keilmuan hukum Islam yang dinamis, beradaptasi dengan kebutuhan, melebur dalam akulturasi kebudayaan, dan terintegrasi dengan keilmuan lainnya. Pembentukan genealogi muncul dari pelbagai ide dan gagasan yang tidak terlepas dari arkeologi pemikiran yang kemudian membentuk teks-teks tertulis dan menitikberatkan pada proses terbentuknya pengetahuan. Pola konstruksi demikian dilanjutkan oleh para dosen di lingkungan Perguruan Tinggi Keagamaan Islam dengan karakteristik kajian hukum Islam yang kontekstual, dialektis, akomodatif, dialogis, dinamis, integratif, dan melalui pendekatan sosiologis. Genealogi itu berkembang dalam kajian studi hukum Islam dengan memanfaatkan modal sosial-intelektual yang dimiliki serta sarana bantuan penelitian dari Direktorat Pendidikan Tinggi 
Keagamaan Islam sebagai arena dan wadah dalam melakukan konstruk analisis berkelanjutan dalam studi hukum Islam. 


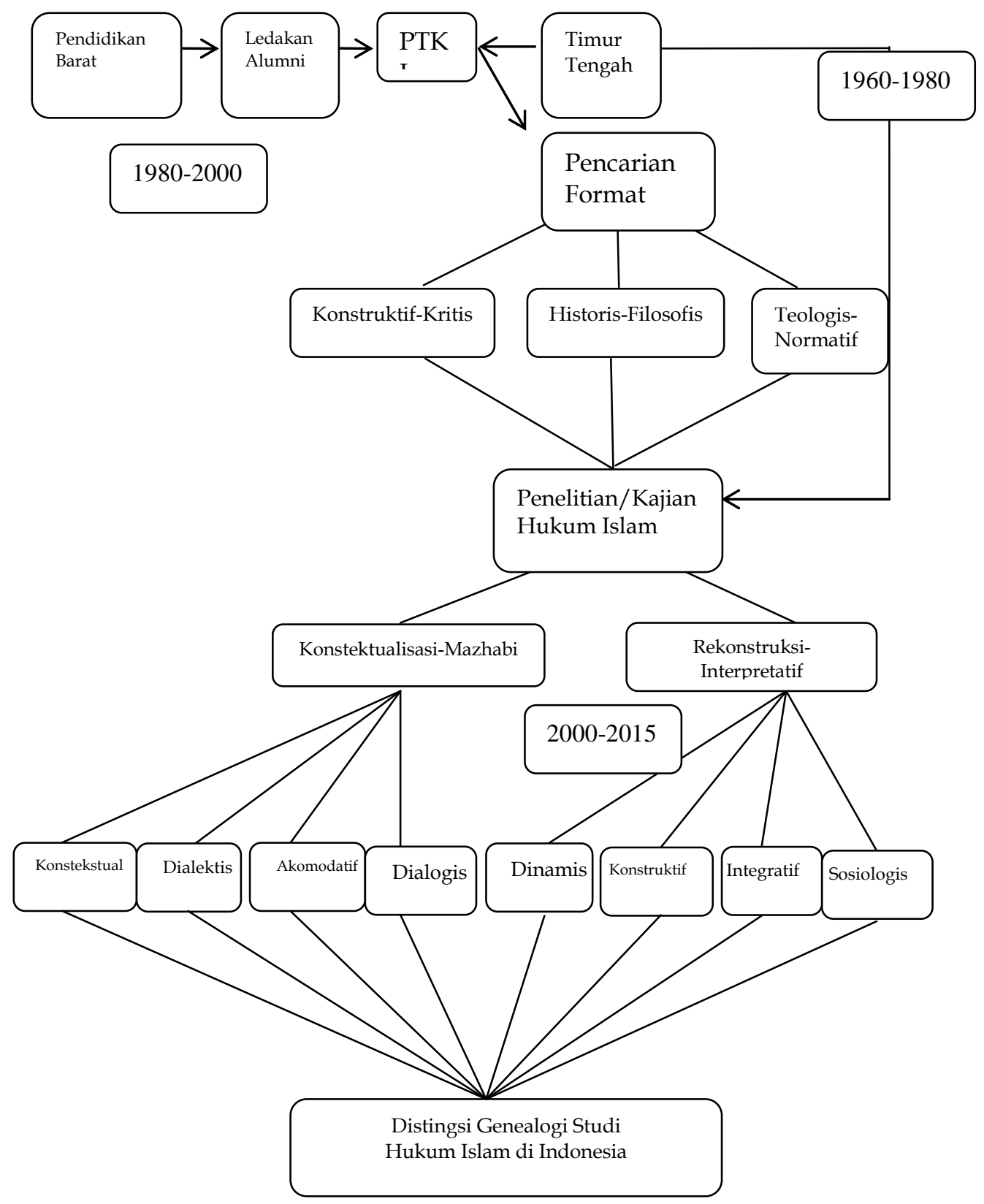




\section{Daftar Pustaka}

Abdullah, M. Amin, "Bangunan Baru Epistemologi Keilmuan Studi Ilmu Hukum Islam dalam Merespon Globalisasi" dalam Jurnal Asy-Syir'ah: Jurnal Ilmu Syariah dan Hukum, Vol. 46 No II, (JuliDesember 2012).

Azizy, A. Qodri, Eklektisisme Hukum Nasional: Kompetisi antara Hukum Islam dan Hukum Umum. Yogyakarta: Gama Media, 2002.

, Pengembangan Ilmu-Ilmu Keislaman, Semarang: Aneka Ilmu, 2004.

, Reformasi Bermazhab: Sebuah Ikhtiar Menuju Ijtihad SaintifikModern. Jakarta: Teraju, 2003.

Azhar Basyir, Ahmad. "Corak Lokal dalam Hukum Positif Islam di Indonesia: Sebuah Tinjauan Filosofis", dalam Mimbar Hukum, No. 13, 1994.

Fadhil Lubis, Nur. Hukum Islam dalam Kerangka Teoritis Figh dan Tata Hukum Indonesia. Medan: Pustaka Widyasarana, 1995.

. "Islamic Legal Literature and Substantive Law in Indonesia" Studia Islamika, Indonesian Journal for Islamic Studies, Volume 4, No. 4, (1997).

Fuad, Mahsun. Hukum Islam Indonesia, Dari Nalar Partisipatoris Hingga Emansipatoris. Yogyakarta: LKiS, 2013.

Foucault, Michel. "Genealogy and Social Criticism" dalam The Postmodern Turn: New Perspectives on Social Theory, S Seidman (Eds). Cambridge: Cambridge Universiy Press, 1994.

. "Nietzche, Genealogy, History", dalam From Modernism to Postmodernism: An Anthology, L. Cahoone (Eds). Cambridge: Blackwell Publisher, 1996.

Hasan, Noorhaidi, "Meretas Involusi Kajian Hukum Islam di Indonesia: Pengalaman Fakultas Syariah dan Hukum UIN Sunan Kalijaga Yogyakarta", Asy-Syir'ah: Jurnal Ilmu Syariah dan Hukum, Vol. 46, No. II, Juli-Desember, (2012): 388-398.

Hariyanto, Erie. "Qua Vadis the Quality of Online Scientific Journal Publishing in State Islamic University (PTKIN)." Khizanah alHikmah Jurnal Ilmu Perpustakaan, Informasi, dan Kearsipan 4, no. 1 (7 Juni 2016): 76-90. https:/ / doi.org/10.24252/kah.v4i1a7.

Hazairin. Tujuh Serangkai tentang Hukum. Jakarta: Tintamas, 1874.

Hidayat, Komaruddin. Problem dan Prospek IAIN: Antologi Pendidikan Tinggi Islam. Jakarta: Departemen Agama RI, 2000. 
Hossen, Ibrahim, "Kerangka Landasan Pemikiran Islam" dalam Mimbar Ulama, No. 91, (1985).

Hossen, Ibrahim. "Fiqih Siyasah dalam Tradisi Pemikiran Islam Klasik" Jurnal Ulumul Qur'an, No. II, (1996).

Kamali, M. Hasyim, "Fiqh Adaptation to Social Reality", dalam The Muslim Word, Vol. XXXXVI, No. 1, 1996.

Liebesny, Herbert J. "Stability and Change in Islamic Law," Middle East Journal, Vol. 21, No. 1, (1967).

Mahfudh, Sahal. Nuansa Figh Sosial. Yogyakarta: LKiS, 1994. "Ijtihad Sebagai Sebuah Kebutuhan". Majalah Pesantren, No. 2, Vol. II, (1985).

Mastuki. Perguruan Tinggi Agama Islam di Indonesia: Sejarah Pertumbuhan dan Perkembangan. Jakarta: Direktorat Jenderal Kelembagaan Agama Islam, 2003.

Mas'udi, Masdar F. Agama Keadilan: Risalah Zakat (Pajak) dalam Islam. Jakarta: P3M, 1991.

Minhaji, Akh. Islamic Law and Local Tradition: A Socio Historical Approach. Yogyakarta: Kurnia Kalam Semesta Press, 2008.

Moulin, Anne Marie. “How To Write The History of Modern Surgery in The Arab and Muslim World?: Methodological Problems and Epistemological Issues:, Majallehye Tarikh-e 'Elm 5, 1385, (2011).

Mudzhar, M Atho. Pendekatan Studi Islam Dalam Teori dan Praktik. Yogyakarta: Pustaka Pelajar, 2007.

"Studi Hukum Islam dengan Pendekatan Sosiologi" dalam Seri Kumpulan Pidato Guru Besar: Rekonstruksi Metodologi IlmuIlmu Keislaman. Yogyakarta: Suka Press, 2003.

"Studi Hukum Islam dengan Pendekatan Sosiologi", pidato pengukuhan Guru Besar Madya Ilmu Sosiologi Hukum Islam pada IAIN Sunan Kalijaga Yogykarta, 15 September 1999.

" "Kajian Ilmu-Ilmu Syariah di Perguruan Tinggi: Sudahkah Merespon Tuntutan Masyarakat?", Asy-Syir'ah: Jurnal Ilmu Syariah dan Hukum, Vol. 46, No. II, (Juli-Desember, 2012).

Musahadi, "Islam sebagai Sasaran Studi: Indentifikasi Awal terhadap Problem, Pola, dan Pendekatan Studi Islam di Indonesia", dalam Proceeding ACIS V, (Jakarta: Direktorat Pendidikan Tinggi Islam, 2005.) 
Riyanto, Waryani Fajar. Mazhab Sunan Kalijaga: Epistemologi Studi Hukum Islam Integratif. Yogyakarta: Kurnia Kalam Semesta dan Fakultas Syariah UIN Sunan Kalijaga Yogyakarta: 2014. ,Studi Islam Indonesia 1950-2014: Rekonstruksi Sejarah Perkembangan Studi Islam Integratif di Program Pascasarjanaa Perguruan Tinggi Agama Islam (PTAI). Depok: Kurnia Salam Semesta, 2014.

Sarjan, M Andi. "Hasbi Ash-Shiddiqie wa Tajdid al-Fiqh fi Indunisiya," Studia Islamika, Indonesian Journal for Islamic Studies, Volume 3, No. 3 (1996).

Salahuddin, Marwan. "Model Pengembangan Pendidikan Tinggi Islam di Indonesia," Ulumuna: Jurnal Studi Keislaman, Vol. 18, No. 1 (2014).

Wahid, Abdurrahman. "Hukum Islam sebagai Penunjang Pembangunan", dalam Jurnal Prisma, No. 14, (Agustus 1975).

Yafie, Ali. Menggagas Fiqih Sosial. Bandung: Mizan, 1994. 